\title{
Improved lithium-ion battery anode capacity with a network of easily fabricated spindle-like carbon nanofibers
}

\author{
Mengting Liu, Wenhe Xie, Lili Gu, Tianfeng Qin, Xiaoyi Hou and Deyan He*
}

\author{
Full Research Paper \\ Address: \\ School of Physical Science and Technology, Key Laboratory for \\ Magnetism and Magnetic Materials of the Ministry of Education, \\ Lanzhou University, Lanzhou 730000, China \\ Email: \\ Deyan $\mathrm{He}^{*}$ - hedy@|zu.edu.cn \\ * Corresponding author \\ Keywords: \\ carbon nanofiber network; electrospinning; lithium-ion battery; \\ manganese oxide; nitrogen modification
}

Beilstein J. Nanotechnol. 2016, 7, 1289-1295.

doi:10.3762/bjnano.7.120

Received: 27 June 2016

Accepted: 31 August 2016

Published: 14 September 2016

This article is part of the Thematic Series "Physics, chemistry and biology of functional nanostructures III".

Guest Editor: A. S. Sidorenko

(c) 2016 Liu et al.; licensee Beilstein-Institut.

License and terms: see end of document.

\begin{abstract}
A novel network of spindle-like carbon nanofibers was fabricated via a simplified synthesis involving electrospinning followed by preoxidation in air and postcarbonization in Ar. Not only was the as-obtained carbon network comprised of beads of spindle-like nanofibers but the cubic $\mathrm{MnO}$ phase and $\mathrm{N}$ elements were successfully anchored into the amorphous carbon matrix. When directly used as a binder-free anode for lithium-ion batteries, the network showed excellent electrochemical performance with high capacity, good rate capacity and reliable cycling stability. Under a current density of $0.2 \mathrm{~A} \mathrm{~g}^{-1}$, it delivered a high reversible capacity of $875.5 \mathrm{mAh} \mathrm{g}^{-1}$ after 200 cycles and $1005.5 \mathrm{mAh} \mathrm{g}^{-1}$ after 250 cycles with a significant coulombic efficiency of $99.5 \%$.
\end{abstract}

\section{Introduction}

Lithium-ion batteries (LIBs) have been identified as one of the most advanced inventions in high energy density storage devices and are extensively utilized in various electronic systems for mobile phones, computers and vehicles [1-3]. It is common knowledge that the capacity and energy density of LIBs are highly dependent on the electrode materials. Commercial graphite, with low specific capacity and poor rate capability, no longer meets the urgent requirements of modern technologies as an anode material for LIBs [4,5]. Hence, exploring new candidates with higher energy density and better cycling endurance becomes imperative.
Presently, transition metal oxides are the focus of intensive efforts for LIB anode materials due to their remarkable specific capacity, low cost and environmental compatibility [6-11]. Manganese oxide $(\mathrm{MnO})$ is a particularly good choice owing to its high theoretical specific capacity of $755 \mathrm{mAh} \mathrm{g}^{-1}$, low conversion potential and small voltage hysteresis $[8,12,13]$. However, as a typical perovskite semiconductor, $\mathrm{MnO}$ usually suffers inherently poor conductivity and severe volume change during $\mathrm{Li}^{+}$insertion/extraction, which can seriously lead to capacity fading and further limit its application $[4,5,8]$. Encouragingly, Liu et al. reported a high capacity of $797.6 \mathrm{mAh} \mathrm{g}^{-1}$ at 
$0.1 \mathrm{~A} \mathrm{~g}^{-1}$ by embedding $\mathrm{MnO}$ nanoparticles in carbon microsheets [14]. Zhao et al. prepared a composite of $\mathrm{MnO}$ and reduced graphene with a capacity of $900 \mathrm{mAh} \mathrm{g}^{-1}$ at $0.1 \mathrm{~A} \mathrm{~g}^{-1}$ [7]. Cui et al. obtained a capacity of $841 \mathrm{mAh} \mathrm{g}^{-1}$ at $0.1 \mathrm{~A} \mathrm{~g}^{-1}$ by combing pompon-like $\mathrm{MnO}$ nanocrystallites with carbon nanotube scaffolds [12]. Wang et al. and Zhao et al. claimed that the electrospun $\mathrm{MnO}-\mathrm{C}$ composite nanofibers preformed high reversible capacities of 663 and $1082 \mathrm{mAh} \mathrm{g}^{-1}$, respectively, at a current density of $0.1 \mathrm{~A} \mathrm{~g}^{-1}$ [5,13]. On the whole, hybridizing $\mathrm{MnO}$ and carbon materials can effectively resolve problems such as the high conductivity of the carbon materials and allows a buffering for the volume expansion or contraction to some degree. Moreover, many studies have shown that $\mathrm{N}$ modification can improve the conductivity and $\mathrm{Li}^{+}$storage performance of carbon materials $[4,8,15]$. Based on these pioneer works, the electrochemical properties of a system consisting of carbon materials, $\mathrm{MnO}$ nanostructures and a $\mathrm{N}$ element should be further studied for the development of high-performance LIBs.

Various $\mathrm{MnO}-\mathrm{C}$ composites with controlled nanostructures have been synthesized for LIB electrodes to date [4,8,14,16-21]. However, most of the synthesis strategies were two-step routes, combing hydrothermal reaction and other post-treatments. Additionally, the nanostructures synthesized by hydrothermal processes are highly sensitive to the reaction parameters and difficult to repeat. At the same time, the route of electrospinning followed by heat treatment has received significant attention because of its simplicity, high efficiency and versatility for preparation of diverse one-dimensional structures $[5,13,22,23]$.

In this work, a network of spindle-like carbon nanofibers anchored with $\mathrm{MnO}$ and $\mathrm{N}$ for LIB anodes was fabricated via a simplified synthesis route involving electrospinning followed by preoxidation in air and postcarbonization in Ar. The microstructure, chemical composition and electrochemical lithium storage performance were investigated in detail. As a binderfree LIB anode, the network impressively delivered a high reversible capacity of $875.5 \mathrm{mAh} \mathrm{g}^{-1}$ after 200 cycles and $1005.5 \mathrm{mAh} \mathrm{g}^{-1}$ after 250 cycles with a coulombic efficiency of more than $99.5 \%$ at a current density of $0.2 \mathrm{~A} \mathrm{~g}^{-1}$.

\section{Results and Discussion}

Figure 1a shows a typical SEM image of the as-fabricated nework, which consists of an abundance of beaded nanofibers with a smooth surface, random orientation and several micrometers in length. The unique morphology of the nanofibers is characterized by connected spindle-like beads with ultrafine fibers connected one-by-one along the long axis. The crosssectional diameter of the beads and fibers are in the range of 350-400 $\mathrm{nm}$ and 80-100 nm, respectively. The observation derived from the TEM image shown in Figure $1 \mathrm{~b}$ verifies the SEM image results. Earlier reports have indicated that the formation of the spindle-like beads on the electrospun nanofibers depends mainly on the viscosity and surface tension of the spinning solution, spinning voltage and receving distance [24,25]. Viewed as a whole, these beaded nanofibers are closely entangled with each other and develop a robust multilayer network, which can be directly used as a binder-free LIB eletrode. Additionally, lithium ions can insert adequately into the network through crevasses between these interlaced nanofibers. Hence, the novel network makes a good LIB electrode.

Figure 2a displays the XRD pattern of the sample. The distinct diffraction peaks at $35.2^{\circ}, 40.8^{\circ}, 59.0^{\circ}, 69.9^{\circ}$ and $73.4^{\circ}$ can be respectively assigned to the (111), (200), (220), (311) and (222)

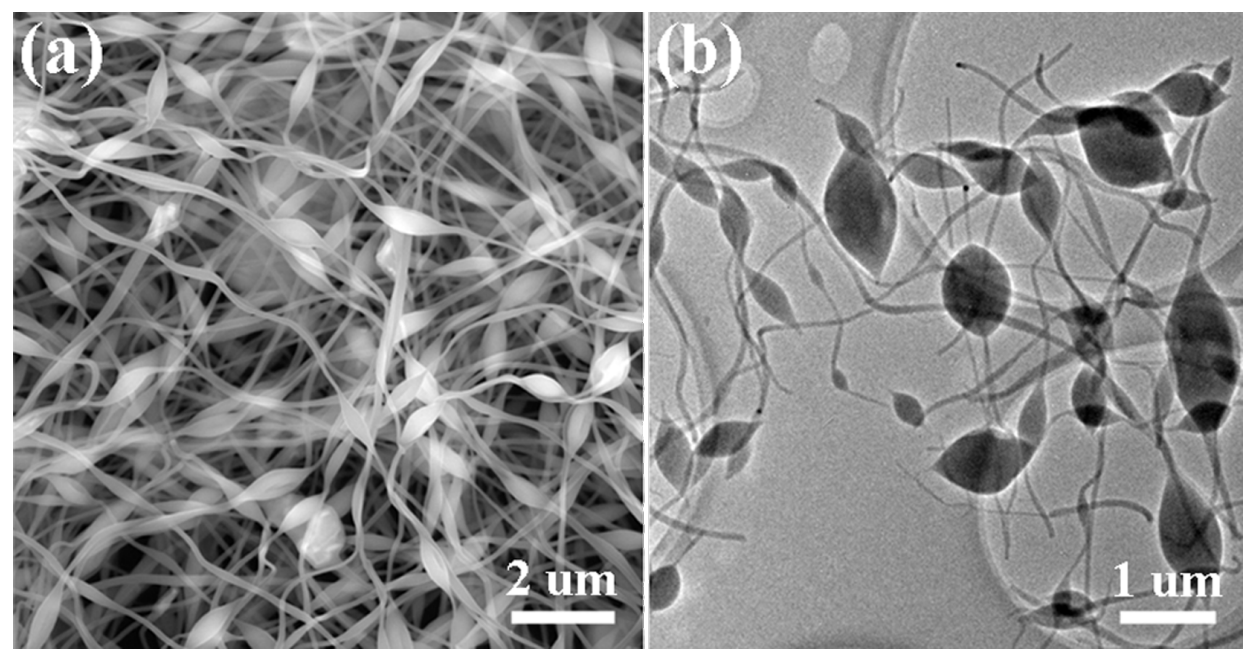

Figure 1: (a) SEM and (b) TEM images of the network of spindle-like carbon nanofibers anchored with $\mathrm{MnO}$ and $\mathrm{N}$. 

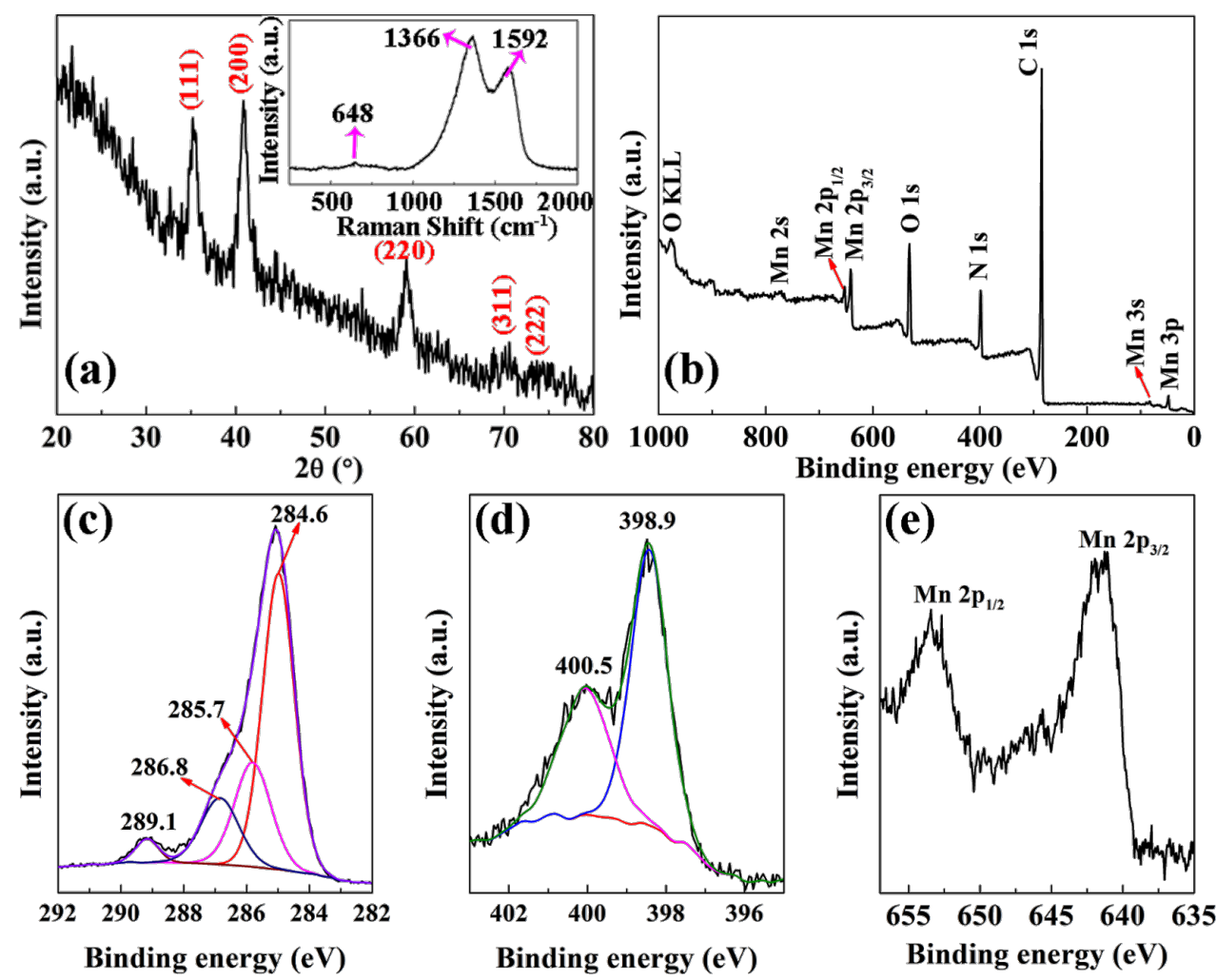

Figure 2: (a) XRD pattern and Raman spectrum (inset), (b) full scan XPS spectrum, (c-e) high-resolution XPS spectra of C 1s, N 1s, and Mn 2p of the spindle-like carbon nanofibers anchored with $\mathrm{MnO}$ and $\mathrm{N}$.

planes of cubic MnO (JCPDS 07-0230) [5]. The broad peaks with weak intensity indicate that a low content of nanocrystalline $\mathrm{MnO}$ is found in the sample. No obvious carbon signals could be observed in the XRD pattern, meaning that the carbon nanofibers derived from the carbonization of the polyacrylonitrile (PAN) precursor has an amorphous structure. The Raman spectrum of the sample is shown in the inset of Figure 2a. The weak signal at about $648 \mathrm{~cm}^{-1}$ can be attributed to the $\mathrm{Mn}-\mathrm{O}$ vibration $[4,8]$. The other two peaks at about 1366 and $1592 \mathrm{~cm}^{-1}$ correspond to the D-band and G-band of disordered carbon and graphitic carbon, respectively. The higher intensity of the D-band means that the amorphous carbon has more defects and can offer more lithium storage sites $[8,26]$. It also reveals that the major component of the obtained beaded nanofiber network is amorphous carbon with a small amount of $\mathrm{MnO}$, which is in accordance with the XRD results. Moreover, an XPS investigation was performed to clarify the elements and their chemical states on the surface of the samples. All the XPS spectra were calibrated by the binding energy of $\mathrm{C} 1 \mathrm{~s}$ at $284.6 \mathrm{eV}$. Apart from the peaks of Mn, O and C, as shown in Figure 2b, elemental $\mathrm{N}$ can be observed in the full scan XPS spectrum. The high-resolution XPS spectrum of $\mathrm{C} 1 \mathrm{~s}$ shown in Figure 2c are fitted into four peaks centered at about 289.1, 286.8, 285.7 and $284.6 \mathrm{eV}$, corresponding to $\mathrm{C}-\mathrm{O}, \mathrm{C}-\mathrm{O}-\mathrm{C}$
$\mathrm{N}-\mathrm{C}$ and $\mathrm{C}-\mathrm{C}$ bonds, respectively $[4,8]$. In Figure $2 \mathrm{~d}$, the two overlapped peaks at 400.5 and $398.9 \mathrm{eV}$ in the high-resolution XPS spectrum of $\mathrm{N} 1 \mathrm{~s}$ are assigned to the $\mathrm{C}=\mathrm{N}$ (pyridinic nitrogen) and $\mathrm{C}-\mathrm{N}$ (pyrrolic nitrogen) bonds, respectively $[4,8,11]$. As shown in Figure $2 \mathrm{e}$, the Mn $2 \mathrm{p}$ spectrum contains two peaks at $653.2 \mathrm{eV}$ and $641.5 \mathrm{eV}$, which can be respectively attributed to $\mathrm{Mn} 2 \mathrm{p}_{1 / 2}$ and $\mathrm{Mn} 2 \mathrm{p}_{3 / 2}$ configurations of $\mathrm{Mn}^{2+}$ in $\mathrm{MnO}[4,8,20]$. Based on the full XPS spectrum, the relative content of $\mathrm{MnO}, \mathrm{N}$ and $\mathrm{C}$ are estimated to be $11.7 \%, 11.7 \%$ and $76.6 \%$, respectively.

The electrochemical performance of the beaded nanofiber carbon network anchored with $\mathrm{MnO}$ and $\mathrm{N}$ was investigated as a working electrode of CR2032-type coin cell with lithium foil as the counter and reference electrodes. Figure $3 \mathrm{a}$ shows the typical cyclic voltammetry (CV) curves of the initial three cycles. In the first discharge-charge cycle, the remarkable peak at about $0.34 \mathrm{~V}$ indicates that $\mathrm{Mn}^{2+}$ is reduced to $\mathrm{Mn}^{\circ}[4,20]$. In the second and third cycle, the peak slightly shifts to a higher voltage of $0.37-0.39 \mathrm{~V}$, which is probably due to the improved kinetics and utilization efficiency of $\mathrm{MnO}$ or the microstructure change after the first lithiation process $[5,7,27]$. In the anodic scan, the broad peak centered at $1.31 \mathrm{~V}$ relates to the decomposition of $\mathrm{Li}_{2} \mathrm{O}$ and regeneration of $\mathrm{MnO}$, which shifts to 
$1.33-1.36 \mathrm{~V}$ in the second and third cycle $[8,15,20]$. Additionally, the weak peak centered at $2.35 \mathrm{~V}$ may be ascribed to the re-oxidation of $\mathrm{Mn}^{2+}$ to a higher oxidation state through a new electrochemical reaction $[4,7,27]$. After the first cycle, the CV curves are well-overlapped, declaring a good electrochemical reversibility and structural stability of the electrode. These results are confirmed by the plateaus in the galvanostatic discharge-charge profiles shown in Figure 3b. An initial discharge capacity of $1188.6 \mathrm{~mA} \mathrm{~h} \mathrm{~g}^{-1}$ is obtained, which is much higher than pure $\mathrm{MnO}\left(755 \mathrm{mAh} \mathrm{g}^{-1}\right)$ and three-fold higher than the theoretical values of pure carbon $\left(372 \mathrm{mAh} \mathrm{g}^{-1}\right)$. The initial charge capacity is $900.1 \mathrm{mAh} \mathrm{g}^{-1}$, leading to a coulombic efficiency of $75.8 \%$. The capacity difference between the initial charge and discharge mainly owes to the electrochemically driven electrolyte degradation, which results in the formation of solid electrolyte interface (SEI) films on the surface of electrode [8,28]. In the 2 nd, 10 th and 50th cycle, both of the discharge and charge curves become shorter due to the ordinary capacity fading. Nevertheless, the capacity begins to increase after the 100th cycle. Many previous works have reported this similar phenomenon of the capacity first decreasing and then increasing $[4,8,23,28]$. For this given system, this should be mainly due to the activation of the material, the formation of a higher oxidation state of $\mathrm{Mn}$ and the reversibility improvement for the conversion reaction. Figure $3 \mathrm{c}$ shows the rate capacity tested by the stepwise increase in the current density from 0.2 to $2.0 \mathrm{~A} \mathrm{~g} \mathrm{~g}^{-1}$. When it returns to $0.2 \mathrm{~A} \mathrm{~g}^{-1}$ again, the capacity recovers to $860.7 \mathrm{mAh} \mathrm{g}^{-1}$ and maintains this value until the
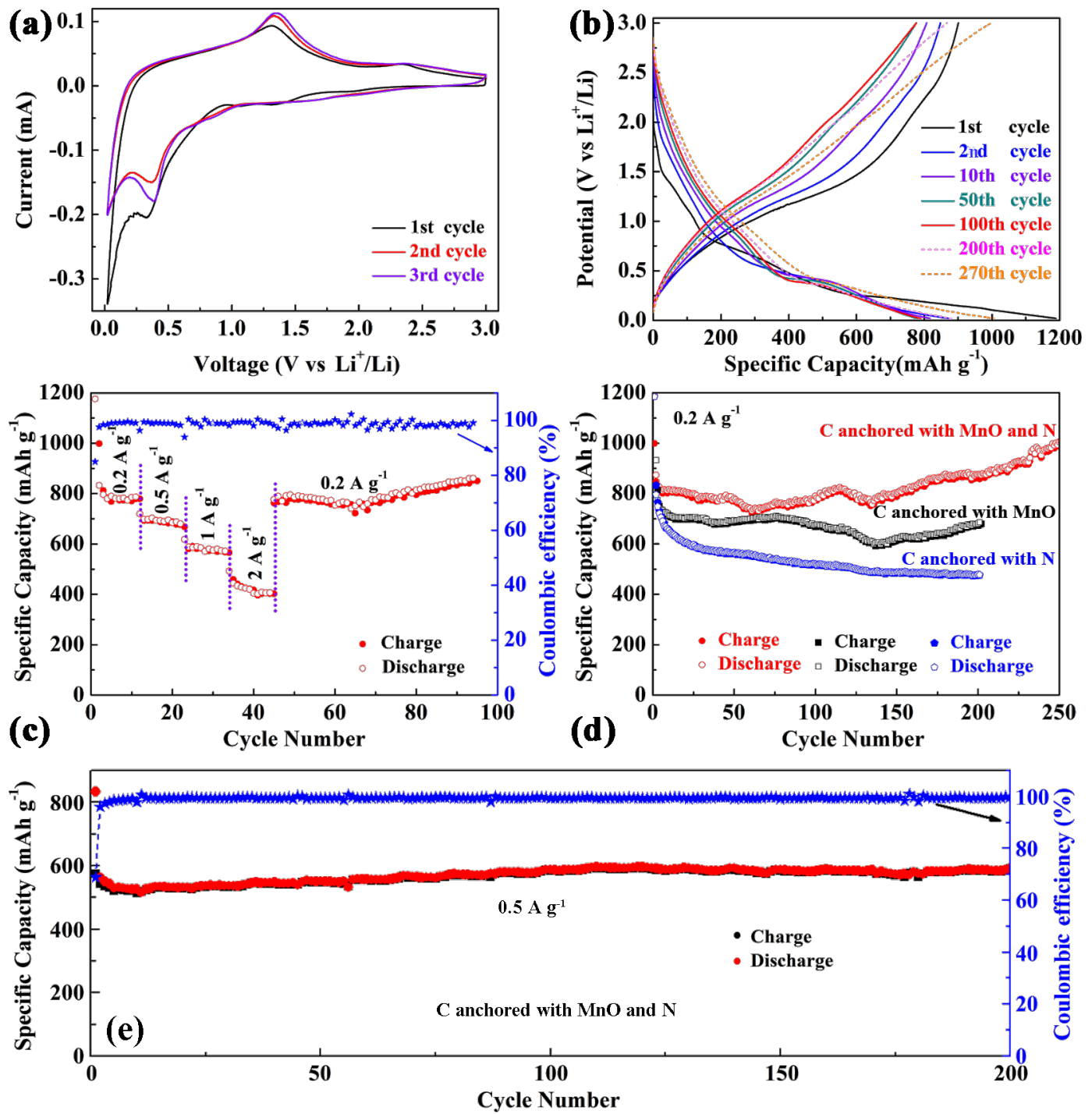

Figure 3: (a) Cyclic voltammetry curves, (b) galvanostatic discharge-charge profiles, (c) rate capacity, and (d, e) cycling performance of the network of spindle-like carbon nanofibers anchored with $\mathrm{MnO}$ and $\mathrm{N}$. 
94th cycle without fading. Additionally, the coulombic efficiency is considerably high. To further investigate the long-term cycling performance of the electrode, the same cell with the beaded nanofiber carbon network anchored with $\mathrm{MnO}$ and $\mathrm{N}$ was tested as working electrode at $0.2 \mathrm{~A} \mathrm{~g}^{-1}$ and the cycling curve is shown in Figure 3d. It reveals that the capacity slightly reduces at first, then basically maintains at a constant value, and finally increases gradually upon cycling. These results are in good accordance with the galvanostatic discharge-charge tests. When the cell is tested to the 200th cycle, the reversible capacity is maintained to $875.5 \mathrm{mAh} \mathrm{g}^{-1}$, which is much larger than those of 672 and $479.1 \mathrm{mAh} \mathrm{g}^{-1}$ for the control samples of carbon anchored with $\mathrm{MnO}$ and carbon anchored with $\mathrm{N}$, respectively. It is worth noting that the reversible capacity is as high as $1005.5 \mathrm{mAh} \mathrm{g}^{-1}$ when the cell is tested to the 250 th cycle. As listed in Table 1, such a high capacity is impressive among the numerous, relevant, previous works on MnO-C-composite-based LIB anodes. To further identify the cycling performance of the networked carbon anode anchored with $\mathrm{MnO}$ and $\mathrm{N}$, a cell was cycled at a higher current density of $0.5 \mathrm{~A} \mathrm{~g}^{-1}$. As shown in Figure 3e, it delivers a reversible specific capacity of $591 \mathrm{mAh} \mathrm{g}^{-1}$ after 200 cycles with a considerable coulombic efficiency of over $98.9 \%$. Based on the above analysis, such a reliable electrochemical performance of the enhanced reversible capacity, the good rate capacity and significant cycle stability may be mainly attributed to the high theoretical capacity of $\mathrm{MnO}$, the improved conductivity of carbon anchored with $\mathrm{N}$, and the robust beaded nanofiber network with structural endurance that effectively alleviates the volume change of the electrode during lithium insertion-extraction.

\section{Conclusion}

A novel beaded nanofiber carbon network anchored with $\mathrm{MnO}$ and $\mathrm{N}$ was fabricated via a synthesis route of electrospinning followed by preoxidation in air and postcarbonization in Ar. Compared with the beaded nanofiber carbon network anchored with $\mathrm{MnO}$ and anchored with $\mathrm{N}$, it exhibited an enhanced reversible capacity with good rate capacity and significant recoverability when used as a LIB anode. This is mainly attributed to the high theoretical capacity and enhanced reaction kinetics of $\mathrm{MnO}$, the improved conductivity of carbon anchored with $\mathrm{N}$, and the robust structural endurance, effectively alleviating the problem of volume change. The work provides another credible work supporting that the transition metal oxide based carbon materials can be successfully applied for LIB electrodes.

\section{Experimental}

\section{Fabrication of the carbon network}

All chemicals were of analytical degree and were used without any purification. A typical procedure is as follows. Firstly, $0.45 \mathrm{~g}$ of manganese acetate tetrahydrate $\left(\mathrm{Mn}(\mathrm{COOH})_{2} \cdot 4 \mathrm{H}_{2} \mathrm{O}\right)$, together with $0.05 \mathrm{~g}$ tripolycyanamide $\left(\mathrm{C}_{3} \mathrm{~N}_{3}\left(\mathrm{NH}_{2}\right)_{3}\right)$ and $0.4 \mathrm{~g}$ PAN were dissolved in $5 \mathrm{~mL} N, N$-dimethylformamide (DMF) with continuous stirring for several hours at $60{ }^{\circ} \mathrm{C}$ to obtain a

\begin{tabular}{|c|c|c|c|c|c|}
\hline Sample & Preparation strategy & LIB electrode & $\begin{array}{l}\text { Capacity } \\
\text { stability } \\
\left(\mathrm{mAh} \mathrm{g}^{-1}\right)\end{array}$ & $\begin{array}{l}\text { Cycle } \\
\text { number }\end{array}$ & $\begin{array}{l}\text { Current } \\
\text { density } \\
\left(\mathrm{mA} \mathrm{g}^{-1}\right)\end{array}$ \\
\hline Coaxial MnO/N-doped C nanorods [4] & $\begin{array}{l}\text { hydrothermal } \rightarrow \text { polymerization } \rightarrow \\
\text { heat treatment in } \mathrm{Ar} / \mathrm{H}_{2}\end{array}$ & slurry coating & 982 & 100 & 500 \\
\hline MnO-C hybrid nanofibers [5] & electrospinning $\rightarrow$ heat treatment in $\mathrm{Ar}$ & freestanding & 398 & 200 & 200 \\
\hline MnO-C nanofiber membranes [13] & $\begin{array}{l}\text { hydrothermal } \rightarrow \text { electrospinning } \rightarrow \\
\text { heat treatment in } \mathrm{N}_{2}\end{array}$ & slurry coating & 655 & 280 & 500 \\
\hline MnO nanoparticles in C microsheets [14] & $\begin{array}{l}\text { acrylic acid solution } \rightarrow \text { freeze drying } \rightarrow \\
\text { heat treatment in } \mathrm{Ar}\end{array}$ & slurry coating & 798 & 50 & 100 \\
\hline MnO-C nanopeapods [16] & $\begin{array}{l}\text { hydrothermal } \rightarrow \text { solution immersion } \rightarrow \\
\text { heat treatment in } \mathrm{Ar}\end{array}$ & slurry coating & 1119 & 100 & 500 \\
\hline MnO-C coaxial nanowires [18] & $\begin{array}{l}\text { hydrothermal } \rightarrow \text { polymerization } \rightarrow \\
\text { heat treatment in } \mathrm{N}_{2}\end{array}$ & freestanding & 832 & 100 & 100 \\
\hline MnO-C nanowires [19] & $\begin{array}{l}\text { hydrothermal } \rightarrow \text { polymerization } \rightarrow \\
\text { heat treatment in } \mathrm{Ar}\end{array}$ & slurry coating & 970 & 100 & 100 \\
\hline MnO-C core-shell nanowires [20] & $\begin{array}{l}\text { hydrothermal } \rightarrow \text { polymerization } \rightarrow \\
\text { heat treatment in } \mathrm{Ar} / \mathrm{H}_{2}\end{array}$ & slurry coating & 903 & 100 & 100 \\
\hline MnO-C coaxial nanocables [21] & $\begin{array}{l}\text { hydrothermal } \rightarrow \text { solution immersion } \rightarrow \\
\text { heat treatment in } \mathrm{N}_{2}\end{array}$ & slurry coating & 750 & 150 & 200 \\
\hline MnO nanoparticles in C nanofibers [22] & $\begin{array}{l}\text { solvothermal } \rightarrow \text { electrospinning } \rightarrow \text { heat } \\
\text { treatment in } \mathrm{Ar} / \mathrm{H}_{2}\end{array}$ & slurry coating & 575 & 200 & 200 \\
\hline \multirow{2}{*}{$\begin{array}{l}\text { Nanofiber carbon network anchored with } \\
\mathrm{MnO} \text { and } \mathrm{N} \text { (this work) }\end{array}$} & \multirow{2}{*}{$\begin{array}{l}\text { electrospinning } \rightarrow \text { heat treatment in air } \\
\text { and } \mathrm{Ar}\end{array}$} & \multirow[t]{2}{*}{ freestanding } & 1005 & 250 & 200 \\
\hline & & & 591 & 200 & 500 \\
\hline
\end{tabular}


homogenous spinning solution. Secondly, the obtained spinning solution was injected into a plastic syringe equipped with a metal nozzle for electrospinning. The electrospinning was conducted at a high voltage of $11 \mathrm{kV}$, a receive distance of $12 \mathrm{~cm}$, and a feed rate of $0.3 \mathrm{~mL} \mathrm{~h}^{-1}$. Thirdly, the $\mathrm{Mn}(\mathrm{COOH})_{2} /$ $\mathrm{C}_{3} \mathrm{~N}_{3}\left(\mathrm{NH}_{2}\right)_{3} / \mathrm{PAN}$ nanofiber web was deposited on an aluminum foil collector, then peeled off and kept in a tube furnace at $250{ }^{\circ} \mathrm{C}$ for $2 \mathrm{~h}$ in air followed by $600{ }^{\circ} \mathrm{C}$ for another $2 \mathrm{~h}$ in $\mathrm{Ar}$. The heating and cooling rates were $5{ }^{\circ} \mathrm{C} \mathrm{min}{ }^{-1}$. Two control nanofiber carbon networks anchored with $\mathrm{MnO}$ and anchored with $\mathrm{N}$ were fabricated by the same procedure, but the spinning solutions were prepared by dissolving $0.5 \mathrm{~g} \mathrm{Mn}(\mathrm{COOH})_{2} \cdot 4 \mathrm{H}_{2} \mathrm{O}$ and $0.4 \mathrm{~g}$ PAN in $5 \mathrm{~mL} \mathrm{DMF}$, as well as dissolving $0.05 \mathrm{~g} \mathrm{C}_{3} \mathrm{~N}_{3}\left(\mathrm{NH}_{2}\right)_{3}$ and $0.4 \mathrm{~g}$ PAN in another $5 \mathrm{~mL}$ DMF, respectively.

\section{Characterization of the carbon network}

The microstructural and morphological characterization of the as-fabricated carbon networks were conducted by field-emission scanning electron microscopy (FE-SEM, S-4800, Hitachi) and transmission electron microscopy (TEM, FEI, Tecnai $\mathrm{G}^{2}$ F30). X-ray powder diffraction (XRD, X'Pert Pro, Philips), Raman spectroscopy (Jobin-Yvon Horiba, HR800) and X-ray photoelectron spectroscopy (XPS, Kratos, Axis Ultra ${ }^{\text {DLD }}$ ) analyses were carried out to determine the chemical structure and composition of the samples.

\section{Electrochemical characterization of the carbon network}

The electrochemical properties of the carbon networks were studied with a CR2032-type coin cell. The details of the cell assembly can be found in previous works $[11,29]$. The galvanostatic discharge-charge cycling and rate tests of the cells were measured using a Neware BTS-610 multichannel battery tester at room temperature. Cyclic voltammetry measurements were performed over a potential window of $0.02-3.00 \mathrm{~V}$ vs $\mathrm{Li}^{2} / \mathrm{Li}^{+}$at a scanning rate of $0.1 \mathrm{mV} \mathrm{s}^{-1}$ with a CHI-660C electrochemical workstation.

\section{Acknowledgements}

This project was financially supported by the National Natural Science Foundation of China with grant no. 11179038 and the Specialized Research Fund for the Doctoral Program of Higher Education with grant no. 20120211130005.

\section{References}

1. Roy, P.; Srivastava, S. K. J. Mater. Chem. A 2015, 3, 2454-2484. doi:10.1039/C4TA04980B

2. Hu, M.; Pang, X.; Zhou, Z. J. Power Sources 2013, 237, 229-242. doi:10.1016/j.jpowsour.2013.03.024
3. Wei, C.; He, W.; Zhang, X.; Shen, J.; Ma, J. New J. Chem. 2016, 40, 2984-2999. doi:10.1039/C5NJ02212F

4. Gu, X.; Yue, J.; Chen, L.; Liu, S.; Xu, H.; Yang, J.; Qian, Y.; Zhao, X. J. Mater. Chem. A 2015, 3, 1037-1041. doi:10.1039/C4TA05622A

5. Wang, J.-G.; Yang, Y.; Huang, Z.-H.; Kang, F. Electrochim. Acta 2015, 170, 164-170. doi:10.1016/j.electacta.2015.04.157

6. Zhao, Y.; Li, X.; Yan, B.; Xiong, D.; Li, D.; Laws, S.; Sun, X. Adv. Energy Mater. 2016, 6, 1502175. doi:10.1002/aenm.201502175

7. Zhao, Y.; Li, X.; Yan, B.; Li, D.; Laws, S.; Sun, X. J. Power Sources 2015, 274, 869-884. doi:10.1016/j.jpowsour.2014.10.008

8. Xiao, Y.; Wang, X.; Wang, W.; Zhao, D.; Cao, M. ACS Appl. Mater. Interfaces 2014, 6, 2051-2058. doi:10.1021/am405142p

9. Yan, B.; Li, X.; Bai, Z.; Zhao, Y.; Dong, L.; Song, X.; Li, D.; Langford, C.; Sun, X. Nano Energy 2016, 24, 32-44. doi:10.1016/j.nanoen.2016.04.002

10. Cai, D.; Li, D.; Ding, L.-X.; Wang, S.; Wang, H. Electrochim. Acta 2016, 192, 407-413. doi:10.1016/j.electacta.2016.02.010

11. Ni, S.; Li, T.; Lv, X.; Yang, X.; Zhang, L. Electrochim. Acta 2013, 91 , 267-274. doi:10.1016/j.electacta.2012.12.113

12. Cui, X.; Wang, Y.; Chen, Z.; Zhou, H.; Xu, Q.; Sun, P.; Zhou, J.; Xia, L.; Sun, Y.; Lu, Y. Electrochim. Acta 2015, 180, 858-865. doi:10.1016/j.electacta.2015.09.012

13. Zhao, X.; Du, Y.; Jin, L.; Yang, Y.; Wu, S.; Li, W.; Yu, Y.; Zhu, Y.; Zhang, Q. Sci. Rep. 2015, 5, 14146. doi:10.1038/srep14146

14. Liu, J.; Chen, N.; Pan, Q. J. Power Sources 2015, 299, 265-272. doi:10.1016/j.jpowsour.2015.09.003

15. Zhang, K.; Han, P.; Gu, L.; Zhang, L.; Liu, Z.; Kong, Q.; Zhang, C.; Dong, S.; Zhang, Z.; Yao, J.; Xu, H.; Cui, G.; Chen, L. ACS Appl. Mater. Interfaces 2012, 4, 658-664. doi:10.1021/am201173z

16. Jiang, H.; Hu, Y.; Guo, S.; Yan, C.; Lee, P.; Li, C. ACS Nano 2014, 8 , 6038-6046. doi:10.1021/nn501310n

17. Chen, W.-M.; Qie, L.; Shen, Y.; Sun, Y.-M.; Yuan, L.-X.; Hu, X.-L.; Zhang, W.-X.; Huang, Y.-H. Nano Energy 2013, 2, 412-418. doi:10.1016/j.nanoen.2012.11.010

18. Wang, J.-G.; Zhang, C.; Jin, D.; Xie, K.; Wei, B. J. Mater. Chem. A 2015, 3, 13699-13705. doi:10.1039/c5ta02440d

19. Wang, J.-G.; Jin, D.; Liu, H.; Zhang, C.; Zhou, R.; Shen, C.; Xie, K.; Wei, B. Nano Energy 2016, 22, 524-532. doi:10.1016/j.nanoen.2016.02.051

20.Zhang, C.; Wang, J.-G.; Jin, D.; Xie, K.; Wei, B. Electrochim. Acta 2015, 180, 990-997. doi:10.1016/j.electacta.2015.09.050

21. Zhang, G.; Wu, H. B.; Hostera, H. E.; Lou, X. W. Energy Environ. Sci. 2014, 7, 302-305. doi:10.1039/c3ee43123a

22. Yang, G.; Li, Y.; Ji, H.; Wang, H.; Gao, P.; Wang, L.; Liu, H.; Pinto, J.; Jang, X. J. Power Sources 2012, 216, 353-362. doi:10.1016/j.jpowsour.2012.05.092

23. Liu, B.; Hu, X.; Xu, H.; Luo, W.; Sun, Y.; Huang, Y. Sci. Rep. 2014, 4, 4229. doi:10.1038/srep04229

24. Fong, H.; Chun, I.; Reneker, D. H. Polymer 1999, 40, 4585-4592. doi:10.1016/S0032-3861(99)00068-3

25. Liu, Y.; He, J.-H.; Yu, J.-y.; Zeng, H.-m. Polym. Int. 2008, 57, 632-636. doi:10.1002/pi.2387

26. Ding, Y.-S.; Li, W.-N.; laconetti, S.; Shen, X.-F.; DiCarlo, J.; Galasso, F. S.; Suib, S. L. Surf. Coat. Technol. 2006, 200, 3041-3048. doi:10.1016/j.surfcoat.2005.05.040

27. Sun, Y.; Hu, X.; Luo, W.; Xia, F.; Huang, Y. Adv. Funct. Mater. 2013, 23, 2436-2444. doi:10.1002/adfm.201202623 
28. Ni, S.; Lv, X.; Li, T.; Yang, X.; Zhang, L.; Ren, Y. Electrochim. Acta

2013, 96, 253-260. doi:10.1016/j.electacta.2013.02.106

29. Ni, S.; Yang, X.; Li, T. J. Mater. Chem. 2012, 22, 2395-2397.

doi:10.1039/c2jm15394g

\section{License and Terms}

This is an Open Access article under the terms of the Creative Commons Attribution License

(http://creativecommons.org/licenses/by/4.0), which permits unrestricted use, distribution, and reproduction in any medium, provided the original work is properly cited.

The license is subject to the Beilstein Journal of

Nanotechnology terms and conditions:

(http://www.beilstein-journals.org/bjnano)

The definitive version of this article is the electronic one which can be found at:

doi:10.3762/bjnano.7.120 